Egyptian Journal of Rabbit Science, 23 (2): 179 - 202(2013)

\title{
EFFECTS OF DIETARY GINSENG OR PARSLEY SUPPLEMENTATION IN DIETS OF GROWING RABBITS RAISED UNDER TWO DIFFERENT CAGED DESIGN SYSTEMS
}

\author{
Hanan, A. M. Hassanien and Ragaa, E. Abd El-Karim
}

Animal Production Research Institute, Agriculture Research Center, Dokki, Giza, Egypt.

The objective of this study was to determine the effects of dietary supplementation with dried parsley leaves meal, ginseng or their combination (feed additives) on growth performance, digestibility, blood parameters, carcass characteristics, immune response of growing rabbits under two different systems (Flat or semi pyramidal) of caged design condition, as well as, semen characteristics of buck and caecum microbial activity. Seventy two New Zealand White (NZW) rabbits weaned at 6 weeks of age, were randomly divided into four experimental treatment groups $(n=18)$, each with 3 replicated of six rabbits. Rabbits the $1^{\text {st }}$ group were fed the basal diet $(17 \% \mathrm{CP}$ and $2500 \mathrm{kcal} \mathrm{DE} / \mathrm{kg}$ diet) for 90-day feeding period, while those of the $2^{\text {nd }}, 3^{\text {rd }}$ and $4^{\text {th }}$ groups were fed the basal diet supplemented with $1.5 \%$ dried parsley leaves $(D p l)$, or $250 \mathrm{mg} / \mathrm{kg}$ diet ginseng $(G)$ and their combination, respectively, under two different caged system conditions (flat or pyramidal).

Results revealed that, final live body weight $(L B W)$, average daily gain $(A D G)$, and feed conversion ratio $(F C R)$ were improved $(p<0.05)$ with flat than semi pyramidal caged system. Only concentration of total lipid (TL) in blood serum was lower $(P<0.05)$ in flat than in semi pyramidal caged system. However, concentration of total protein (TP), albumin (AL), globulin (GL), cholesterol $(\mathrm{CH})$ and glucose, Ca and $P$, as well as, immune response were not affected significantly by caged design. Slaughter weight were higher $(P<0.05)$, while dressing $(D P)$ percentage and EE content in meat were lower $(P<0.05)$ in flat than with semi pyramidal caged systems.

Rabbits fed ginseng with or without parsley supplemented diets showed significantly $(P<0.05)$ the best values of final $L B W, A D G$, and $F C R$, the highest digestibility coefficients of CP, EE and NFE, as well as, the highest feeding values in term of TDN, DCP and DE, compared with Parsley supplemented diet and control one Otherwise, those fed parsley supplemented diet showed the highest $(P<0.05)$ digestibility coefficients of DM and CF. Parsley supplementation diet had significantly higher concentration of TP and AL than those of other treatments, while GL and 
$P$ did not affected by supplemental treatments. The values of TL, $\mathrm{CH}$ and glucose were significant lower with all tested supplements than control. Inversely Ca concentration was significant higher with tested diets compared with control. All dietary supplements increased $(P<0.05)$ immune response, being the highest for ginseng plus parsley diets.

Ginseng and their combination with Parsley showed significant higher weights at slaughter and hot carcass than those of control or the other supplemental diet. Dressing percentage and weights of kidney, heart and head did not affected by experimental treatments. Liver weight was significant lower for ginseng diet than that of the other treatments. Dietary supplementations had no significant effect on rabbits meat analysis. Most physical semen characteristics, including sperm cell concentration, percentage of mobility and dead spermatozoa were significantly improved due to all supplemental diets compared to control one. The semen ejaculate volume and sperm abnormality concentrations were not affected by treatments. All dietary supplements increased $(P<0.05)$ total count of bacteria and lactobacilli, while pathogenic bacteria (E-coli and Clostridium spp.) had an inverse trends. From the economical point of view, rabbits fed Ginseng supplemented diet and housed flat caged system showed the highest $(P<0.05)$ economic efficiency. Interaction results indicated no significant for previous traits, except for immune response and content of $\mathrm{Ca}$, which were significantly $(P<0.05)$ affected.

In conclusion, results of this study indicated that growing rabbits fed ginseng alone or with Parsley supplemented diets and housed in flat caged system recorded the best growth performance and economical efficiency.

Keywords: Rabbit, Parsley, Ginseng, Digestibility, Blood Biochemical, Immunity, Carcass, Caecum Microbial Activity, Semen Quality.

Economic intensive rabbits production on relatively small scale (small holders or new graduates and inexperienced agricultural engineers) is affected by many factors, particularly environment and nutrition and their interaction. However, housing systems (designing of caged systems) have also an effect on the important traits of meat rabbit production which related to growth performances and respiratory diseases, as well as, behavioral of the rabbits, especially with using a large number of rabbits of improved breeds and strains (Baselga,1990 and Anous and Ayyat, 2002).Housing livestock is designed to suit the prevailing climatic conditions bearing in mind the availability and cost 


\section{EFFECTS OFDIETARY GINSENGORPARSLEY SUPPLEMENTATIONINDIETSOFRABBITS 181}

of materials and local worker's skills (Owen, 1994). Also, housing system has an effect on the growth of rabbits and consequently their carcass composition (Lebas et al., 1986 and Lebas \& Ouhayoun., 1987).

Natural feed additives of plant origin are generally believed to be safer, healthier and less subject to hazards for human beings and animals than antibiotics. One of the mechanisms underlying the health related benefits may be associated with their antioxidant properties (Kim et al., 2011). Many herbs and plant extracts possess antimicrobial activities and antioxidant properties that make them useful as natural animal feed additives(Faixova and Faix, 2008).

Recent studies concentrated on aromatic plants, their extracts and essential oils. This has increased the interest in those herbs that possess characteristics such as antioxidant, anti- stress, lowering cholesterol, and cancer prevention properties in their phenolic compounds (Yildirim and Erener, 2010). These extracts present a mechanism of action based on the alteration of the intestinal microbiota, increased enzyme secretion, improved immune response, morpho-histological maintenance of the gastrointestinal tract and antioxidant activity (Brugalli, 2003; Fascina et al.,2012).

Parsley (Petroseliniumcrispum) leaves, roots and seeds could be used as natural feeding additives. The fresh leaves are rich source of manganese, vitamins and calcium. Leaves, roots and seeds are diuretic, reduce the release of histamines and scavenge skin aging free radicals (Richmond and Mackley, 2000).Parsley's volatile oils, particularly myristicin, have been shown to have significant biological activities(Holst and Engvild, 2000). Some investigators reported that using medicinal and aromatic plants in rabbit diets improved body weight, body weight gain and performance index, (Ibrahim et al., 2004 and Ibrahim, 2005). Also, leafy vegetables like Parsley are valuable sources of different nutrients where they contribute substantially to protein, mineral, vitamins, fiber and other nutrients, which are usually in short supply in daily diets (Solanke and Awonorin, 2002).

Ginseng (Araliacease), also called Asian ginseng, is one of the most renowned herbal plants worldwide, but particularly in Asian countries and has been used for thousands of years to maintain homeostasis of the body and enhance vital energy (Attele et al., 1999; Choi, 2008; Yildirim and Erener, 2010).It is considered an adaptogenic agent that helps to enhance physical performance, promote vitality and stimulate metabolic function. It has previously been documented that bioactive components such as saponins (ginsenosides), antioxidants, peptides, polysaceharides, alkaloids, lignin and polyacetylenes are present in P.ginseng (Sticher, 1998; Palazon et al., 2003; Lü et al., 2009).Among these, the saponins (ginsenosides) are considered the 
principal bioactive ingredients (Palazon et al., 2003) and are believed to possess anti-fatigue and hepatoprotective properties (WU and Zhong, 1999), and improve cardiovascular system dysfunction (Kang et al., 1995). Likewise, numerous studies have demonstrated the pharmaceutical effects of P. ginseng on physical , chemical and biological stress(Takahashi et al., 1992; Shim et al., 2010), systemic immune function (Spelman et al., 2006) and glucose metabolism (Lim et al., 2009). The presences of ginsenoside in the P. ginseng complex contributed to the improvement in the parameters evaluated by its antimicrobial and antioxidant potential, as confirmed by (Takahashi et al., (1992); Kim et al.,(2008), Zhang et al.,(2008) and Lim et al., (2009).

Therefore, the objective of this study was to determine the effects of dietary supplementation of dried Parsley leaves, ginseng meal or their combination on growth performance, blood parameters, digestibility coefficients, carcass characteristics, immune response, as well as , economic efficiency of growing rabbits raised in two different system of caged models design (Flat and Semi- pyramidal) condition.

\section{MATERIALS AND METHODS}

This study was conducted at rabbit farm of the Sakha Experimental Station, belonging to Animal Production Research Institute, Agricultural Research Center during the period from April to June. This work was carried out through the Project Funded by the Council of Agricultural Research and Development.

\section{Animals}

A total of 72 New Zealand White (NZW) rabbits, weaned at 6 weeks of age with an average initial body weight $770.98 \pm 5.62 \mathrm{~g}$ were randomly assigned into four experimental treatments (18 rabbits each) divided into 3 replicates of six rabbits each. All rabbits were kept individually in community battery cages, setup in an open- sided rabbit house, and managed under similar conditions.

\section{Housing models:}

Rabbits were housed individually in two stainless steel individual cages models that differed mainly in the housing area. The first cages model was modified as semi pyramidal housing design $(30 \times 22.5 \times 45 \mathrm{~cm})$, while the second model was normal cage design $(95 \times 35 \times 60 \mathrm{~cm})$ used as flat housing system and both designs provided with feeders and automatic nipple drinkers. This modifying of cage system is designed to suit the small areas, especially with small holders or new graduates and inexperienced agricultural engineers with using a large number of rabbits of improved breeds. 


\section{EFFECTS OFDIETARY GINSENG OR PARSLEY SUPPLEMENTATIONINDIETS OFRABBITS 183}

\section{Experimental design:}

Rabbits in all experimental groups were fed the same basal diet, which was formulated to be isonitrogenous $(17.0 \% \mathrm{CP})$ and isocaloric $(2500 \mathrm{Kcal} \mathrm{DE} / \mathrm{kg})$, and to satisfy the nutrient requirements of growing rabbits according to the NRC (1977) the recommendations. Rabbits in the $1^{\text {st }}$ group were fed the basal diet without supplementation and served as a control group. Meanwhile, those in the $2^{\text {nd }}, 3^{\text {rd }}$ and $4^{\text {th }}$ groups were fed the basal diet supplemented with either $1-5 \%$ dried Parsley leaves (DPL), $250 \mathrm{mg} / \mathrm{kg}$ diet ginseng (Gns) and 1.5\%DPL+250 $\mathrm{mg} / \mathrm{Kg}$ diet Gns, respectively. Ingredients and chemical composition of control ration are shown in Table 1.The chemical composition of air dried Parsley leaves were analyzed by Carpenter and Clegg (1956) as 88.98, 15.24, 1.49, 8.35, 14.50 and $49.40 \%$, for DM, CP, EE, CF, ash and NFE, respectively, and $2850 \mathrm{kcal} / \mathrm{kg}$ as ME. Rabbits in all experimental groups were fed ad. libitum and water was available through water nipple in each cage. All rabbits were kept under the same managerial, hygienic and environmental conditions.

\section{Experimental Procedure:}

Live body weight and feed intake were weekly recorded, then body weight gain and feed conversion ratio were calculated throughout the experimental period from 6 to 13 weeks of age. Dry matter (DM), crude protein $(\mathrm{CP})$, ether extract $(\mathrm{EE})$, crude fiber $(\mathrm{CF})$ and ash of feeds and faces were analyzed according to the methods of AOAC (2000).

\section{Digestibility trials:}

During the last week of the experimental period, four digestibility trails were undertaken on four animals from each group. Rabbits were housed individually in metabolism cages $(40 \times 35 \times 30 \mathrm{~cm})$, which allowed feces and urine being in completely separation for 3 days of collection period. Feed intake was accurately determined and coprophagy was not prevented. Quantitative collection of feces started 24 hours after offering the daily feed, then feces was dried at $60^{\circ} \mathrm{C}$ for $12 \mathrm{~h}$. All collected feces for each animal were mixed, ground and kept for chemical analysis. Fecal apparent digestibility of $\mathrm{DM}, \mathrm{CF}, \mathrm{CP}, \mathrm{EE}, \mathrm{NFE}$ and $\mathrm{OM}$ were determined. Values of total digestible nutrients (TDN) were calculated according to the classic formula described by Cheeke (1987).

\section{Blood biochemical analysis:}

At the end of the experiment (13 weeks of age), four rabbits from each group were used to collect blood samples into centrifuge tubes without anticoagulant. Blood serum was separated by centrifugation of blood samples at $4000 \mathrm{rpm}$ for 15 minutes and kept at $20^{\circ} \mathrm{C}$ till analysis. 
Table 1: Ingredients and calculated chemical composition of basal diet fed to rabbits in all experimental groups.

\begin{tabular}{|c|c|}
\hline Ingredients & $\%$ \\
\hline Clover hay $(12 \%$ CP $)$ & 22.50 \\
\hline Barley grains & 27.25 \\
\hline Wheat bran & 28.90 \\
\hline Soybean meal (44\%CP) & 15.00 \\
\hline Molasses & 3.00 \\
\hline Limestone & 0.70 \\
\hline Di-calcium phosphate & 1.70 \\
\hline Sodium Chloride & 0.50 \\
\hline Mineral Vitamin Premix ${ }^{l}$ & 0.30 \\
\hline Dl-Methionine & 0.15 \\
\hline Total & 100 \\
\hline \multicolumn{2}{|l|}{ Calculated chemical composition $^{2}$} \\
\hline Crude protein, $\%$ & 17.00 \\
\hline Ether extract, \% & 2.99 \\
\hline Digestible energy ( Kcal/ kg) & 2500 \\
\hline Crude Fiber, \% & 12.00 \\
\hline$N D F \% *$ & 36.81 \\
\hline$A D F \%$ ** & 20.38 \\
\hline Hemicellulose, $\%$ *** & 16.43 \\
\hline Calcium, $\%$ & 1.09 \\
\hline Total phosphorus, \% & 0.80 \\
\hline Methionine, \% & 0.41 \\
\hline Lysine, \% & 0.72 \\
\hline \multicolumn{2}{|c|}{ 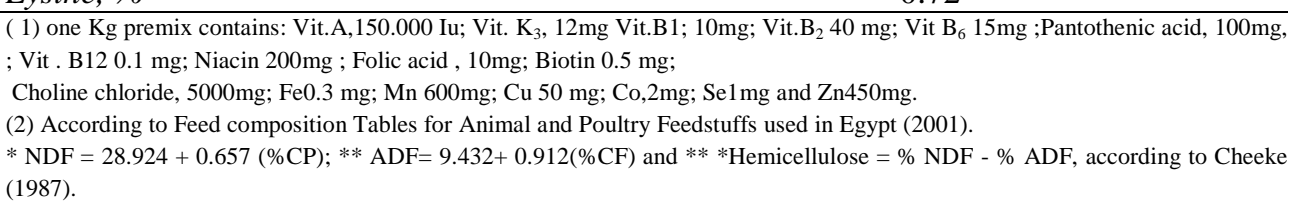 } \\
\hline
\end{tabular}

Concentrations of total protein was determined as described by Gornall et al. (1949), and calcium (Ca) and phosphorus (P) were determined spectrophotometrically in blood serum using commercial kits (BioMeriewx, Laboratory Reagents and Products, France). Albumin was estimated according the method of Tietz (1994) and globulin concentration was calculated by subtracting albumin concentration from total protein concentration.

\section{Determination of antibody titers:}

At 6-wk of age, ovine red blood cells (ORBC), a thymus - dependent antigen as a test antigen were used to quantify the specific antibody response as a measure of humoral immune competence. In each treatment group, four rabbits were intravenously injected with one $\mathrm{ml}$ of $25 \%$ ORBC 


\section{EFFECTS OFDIETARY GINSENGORPARSLEY SUPPLEMENTATIONINDIETSOFRABBITS 185}

suspension that prepared in $0.9 \%$ saline solution. Thereafter, blood samples were collected at 7 days later from the immunized rabbits in each group and then used to determine the primary antibody response in blood plasma. The determination of antibody titers to ORBC was performed using the microtiter technique according to Trout et al., (1996).

\section{Carcass traits:}

At the end of the experimental period (13 weeks of age), four rabbits from each groups were randomly taken and weighed before slaughter. After slaughtering and complete bleeding, the head, pelt, viscera, feet and tail were removed. Weight of hot carcass (dressed weight) was recorded, and then dressing percentage was calculated. Weights of organs, including head, heart, liver and kidney were recorded. Meat samples from the right caudal side of the carcass were taken for chemical analysis. Rabbit meat was analyzed according to the methods of $\mathrm{AOAC}(2000)$.

\section{Semen physical characteristic:}

Semen was collected from each buck at 1 week after natural mating of the female (it was a subject of a similar study), twice a week for three times by means of an artificial vagina using a female teaser rabbit. At each semen collection( $\mathrm{n}=5$ for each buck), ejaculate volume (ml), sperm-cell concentration $\left(\mathrm{X} 10^{6} / \mathrm{ml}\right)$, percentage of sperm motility, percentage of dead and abnormal spermatozoa were determined according to Smyth and Gordon (1967).

\section{Caecum microbial activity:}

The microbial diagnosis examination was carried out on samples of caecum contents (4 males in each) according to Mackie and McCarteny (1953). American public Health Association, APHA (1960) and Difco Mannual (1977).

\section{Statistical analysis :}

The statistical analysis was carried out using the general linear Model program (GLM) of SAS (2004). The obtained data o rabbits were subjected to factorial analysis of variance $(2 \times 4)$ according to the following model:

$$
\mathrm{y}_{\mathrm{ijk}}=\mathrm{u}+\mathrm{T}_{\mathrm{i}}+\mathrm{L}_{\mathrm{j}}+\mathrm{TL}_{\mathrm{ij}}+\mathrm{e}_{\mathrm{ijk}}
$$

Where: $\mathrm{y}_{\mathrm{ijk}}=$ Observed of the tested factor, $\mathrm{u}=$ Overall mean, $\mathrm{T}_{\mathrm{i}}=$ The effect of caged system, $\mathrm{i}=1 \& 2 ; \mathrm{L}_{\mathrm{j}}=$ The effect of dietary supplemented groups. $\mathrm{j}=1 \ldots . .4 ; \mathrm{TL}_{\mathrm{ij}}=$ The interaction between caged systems and dietary supplemented groups and $\mathrm{e}_{\mathrm{ijk}}=$ Random error. 
Differences among means were subjected to Duncan's Multiple Range-Test (Duncan, 1955).

\section{RESULTS AND DISCUSSION}

\section{Growth performance traits}

Results presented in Table (2) showed significant effect $(\mathrm{P}<0.05)$ on designing of caged system on all growth performance parameters. Final live body weight (LBW) at $13 \mathrm{wk}$ of age, average daily gain (ADG) and average daily feed intake $(A D F I)$ were significantly $(\mathrm{P}<0.05)$ higher with flat design of caged system than with semi pyramidal caged system by about 5.14, 7.67 and $5.03 \%$, respectively. Feed conversion ratio (FCR) was significantly $(\mathrm{P}<0.05)$ better in flat design compared to the other design. These results are in accordance with those reported by Ndor et al. (2010), who found significant difference in body weight $(\mathrm{P}<0.05)$ among rabbits reared under three different systems.

Regarding the dietary addition, most of growth parameters were significantly $(\mathrm{P}<0.05)$ improved by adding ginseng or its combination with parsley, being significantly $(\mathrm{P}<0.05)$ better with ginseng plus parsley than control or ginseng alone diets. The beneficial effects of ginseng on growth performance of rabbits was mainly attributed to the alteration of the intestinal microbial, increased enzyme secretion, improved immune response, reducing biological stress, increasing antioxidant activity and consequently improving health status (Brugalli, 2003, Fascina et al., 2012). Additionally, the presence of ginsenoside in the panax ginseng complex contributed to improvement the parameters evaluated by its antimicrobial and antioxidant potential, as well as, assist the absorption of nutrients by increasing the permeability of the small intestinal mucosa as confirmed by Takahashi et al. (1992); Kim et al.,(2008), Zhang et al.(2008) and Lim et al.(2009).

In agreement with the present results, Chrastinová et al.,(2009) found that, the addition of gensing into growing rabbit diets $(30 \mathrm{~g} / 100 \mathrm{~kg})$ improved feed conversion ratio and average daily weight gain $(\mathrm{P}<0.05)$. Similar results were reported with chickens (AO et al., 2011) and rats ( Abdel-Wahhab et al., 2012). However, adding parsley alone did not affect all growth parameters, except final LBW which significantly $(\mathrm{P}<0.5)$ decreased by adding Parsley to the diet of rabbits (Table3). On other variable results on parsley supplementation, Ibrahim et al., (2004) and Ibrahim (2005) demonstrated that parsley $(1 \%)$ supplementation significantly increased the daily feed intake of rabbits as compared with the control group, but no significant differences in feed conversion ratio were observed. Moreover, Azouz (2001) observed no 
EFFECTS OFDIETARY GINSENG ORPARSLEY SUPPLEMENTATIONINDIETS OFRABBITS 187

Table 2 : Growth performance of growing rabbits as affected by designing of caged system, feed additives and their interaction.

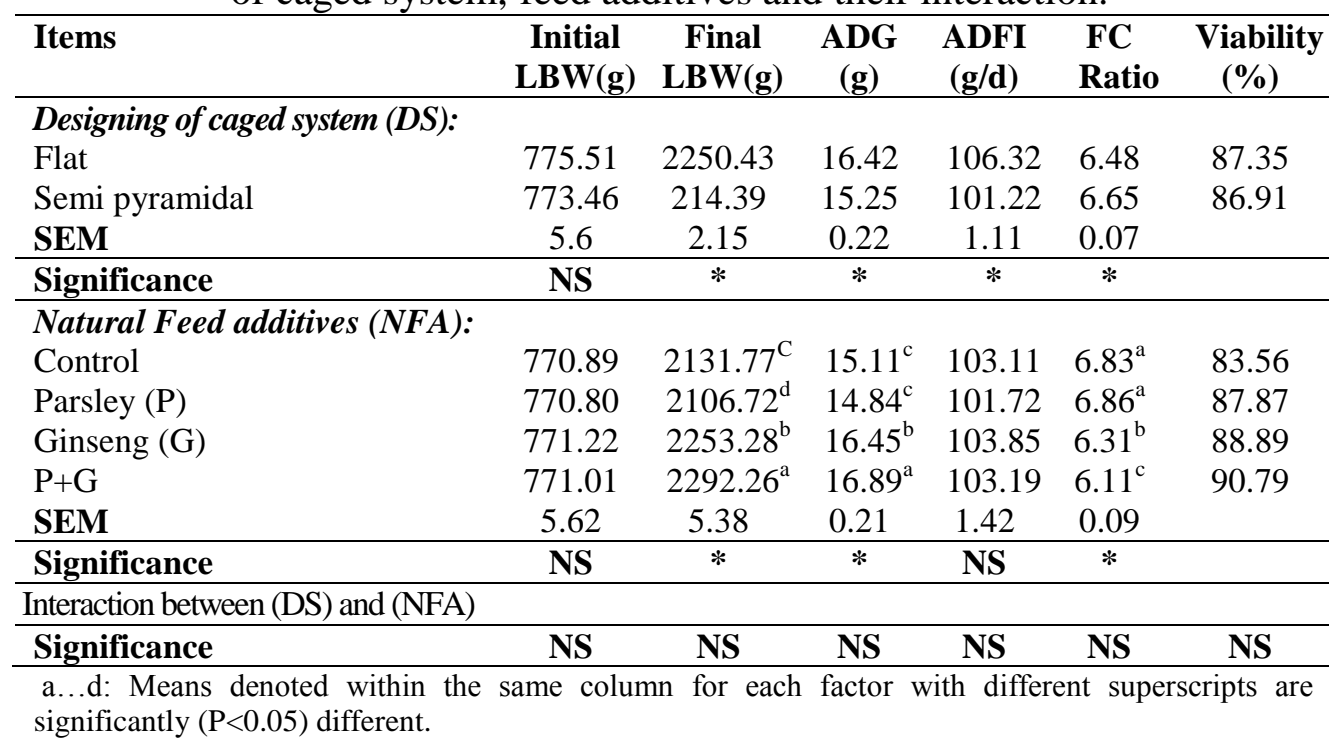

significant differences in feed intake between broilers fed fenugreek seeds and those feed the control diets.

The effect of interaction between dietary supplementation and designing of caged system respecting all growth parameter was not significant (Table 3), indicating superiority of all growth parameters for rabbits housed in flat caged system and fed diet supplemented with ginseng plus parsley.

\section{Digestibility coefficient and feeding values:}

Results in Table (3) showed that rabbits fed diets supplemented with ginseng alone or with parsley had the highest $(\mathrm{P}<0.05)$ digestibility coefficients, of CP, EE and NFE, while those fed parsley supplemented diet showed the highest $(\mathrm{P}<0.05)$ digestibility coefficients of $\mathrm{DM}$ and $\mathrm{CF}$ as compared to the control diet or other dietary supplements. However, parsley and parsley plus ginseng diets significantly $(\mathrm{P}<0.05)$ increased digestion of DM, CP, EE and NFE as compared with the control diet.

These results indicated that rabbits fed the diet supplemented with ginseng alone or with parsley enhanced the digestion of most nutrients, which was associated with increasing their growth performance traits as compared to those fed other dietary supplements. These results may suggest that ginseng supplementation can enhance the digestive processes which associated with microorganisms in the gastrointestinal tract. Most of these 
HANAN HASSANIEN \& RAGAA ABD EL-KARIM 


\section{EFFECTS OFDIETARY GINSENGORPARSLEY SUPPLEMENTATIONINDIETSOFRABBITS 189}

enhancements may be directly related to stimulation of microbial growth and activity in particular proteolytic bacteria and /or ginseng may had a favorable buffering effect on caecal conditions.

Regarding the feeding values (Table 3), TDN, DCP and DE were significantly $(\mathrm{P}<0.05)$ higher with all dietary supplements than those of the control diet, being the highest values were occurred with ginseng alone or combined with parsley supplement as compared to other supplements. In addition, many herbs and plant extracts possess antimicrobial activities and antioxidant properties that make them useful as natural feed additives (Faixova and Faix, 2008). These extracts present a mechanism of action based on the alteration of the intestinal microbiota, increased enzyme secretion, improved immune response, morpho- histological maintenance of the gastrointestinal tract and antioxidant activity(Brugalli, 2003; Fascina et al ., 2012). Because of these benefits, ginseng extracts may exert positive effects on performance in growth rabbits.

\section{Blood parameters:}

Results in Table (4) showed that housing caged system was only affected significantly on concentration of serum total lipids (TL), where semi pyramidal had higher value than the flat one. However, concentrations of other serum biochemical including total protein (TP), albumin (AL), globulin (GL), cholesterol $(\mathrm{CH})$ and glucose, $\mathrm{Ca}$ and $\mathrm{P}$, as well as, immune response were not significantly affected by housing system.

The effect of dietary supplementation was significant $(\mathrm{P}<0.05)$ on serum concentrations of $\mathrm{TP}, \mathrm{AL}, \mathrm{TL}, \mathrm{CH}$, glucose, and $\mathrm{Ca}$, as well as,immune response. But the concentrations of GL, and $\mathrm{P}$ were not significantly affected by dietary supplementation. Results showed that ginseng with or without parsley supplementation significantly $(\mathrm{P}<0.05)$ decreased concentration of total lipids, cholesterol and glucose to the minimal values (within normal range) as compared to other supplements. Ginseng has also been linked to a variety of positive actions. It is a lipotropic that has been shown to prevent and reduced fat accumulation in the liver in both animal and human studies, also white ginseng small compounds had a positive effect on hypercholesterolemia (Lee et al., 2013). These findings were proved by this study by decreasing levels of TL, CH and glucose to the lowest values in blood serum of rabbits fed supplemented diet (Table 4). In close agreement with the present results, Simonová et al. (2008) showed that ginseng extract did not influence negatively biochemical parameters in blood, and there by the dry extract of Eleuthero coccus senticosua is promising for its use in rabbit breeding by supporting physiological parameters. 
Earlier, Qureshi et al.(1983) suggested that dietary ginseng reduced Bhydroxyl -B- methylglutaryl-CoA (HMG-CoA) reductase activity and cholesterol 7- $\alpha$ - hydroxylase activity compared with the diet without ginseng, and suggested that ginsenoside (saponins) is the active agent for the suppression of cholesterogenesis and lipogenesis. Therefore, the reduced cholesterol levels might be corroborated by in ginseng treatments. The relationship between saponinsand cholesterol, which is in line with the previous study in which the ginseng culture by product decreased the cholesterol concentration in laying hens (Jang et al., 2007). In addition, calcium level was increased in response to all additive supplementations compared to that of control. This may be due to increased of plasma calcium level back to the effects of using of ginseng as affected in improvement of bone resistance (Azazi et al., 2011).

Meanwhile, dietary supplementation of parsley had significant $(\mathrm{P}<0.05)$ increase glucose concentration to the highest values. Yet, all dietary supplements significantly $(\mathrm{P}<0.05)$ increased immune response of growing rabbits, being the highest for the combination of ginseng and parsley.

The effect of interaction between dietary supplements and housing system on all blood parameters was not significant, except for cholesterol and $\mathrm{Ca}$ contents (Table 4), indicated that these parameters were affected significantly $(\mathrm{P}<0.05)$ only by dietary supplementation.

\section{Carcass traits and chemical analysis of meat:}

Data in Table (5) showed that slaughter weight (SW) was significantly $(\mathrm{P}<0.05)$ higher for flat caged system than for that of semi pyramidal caged one, although dressing percentage (DP) had significantly $(\mathrm{P}<0.05)$ reverse trend. Similar effect was associated with liver relative weight (LRW). While hot carcass weight relative weights of kidney, heart and head did not influenced by caged systems concerning the effect of dietary supplementation on carcass traits, it could be observed that treatments of ginseng alone or combined with parsley had significant higher weights at slaughter, hot carcass and liver, while dressing percentage, kidney, heart and head were not significantly affected by dietary supplementation .Ginseng plus parsley supplementation showed significantly $(\mathrm{P}<0.05)$ the highest values of slaughter weight and liver weight compared to other treatments. Similar results were found by Rabie et al., (1997) and Rabie and Silágyi (1998).They observed greater breast and high meat yield in broilers fed diets containing sapononin. Liver size significantly $(\mathrm{P}<0.05)$ reduced on diets with saponin alone or along with carnitine. 
EFFECTS OFDIETARY GINSENG ORPARSLEY SUPPLEMENTATIONINDIETSOFRABBITS 191

Table 5. Carcass traits of rabbits as affected by caged system and feed additives and their interaction.

\begin{tabular}{|c|c|c|c|c|c|c|c|}
\hline \multirow[b]{2}{*}{ Items } & \multicolumn{2}{|c|}{ Weight $(\mathrm{g})$} & \multirow[b]{2}{*}{$\begin{array}{c}\text { Dressing - } \\
(\%)\end{array}$} & \multicolumn{4}{|c|}{ Weight of organ relative to $\mathrm{BW}$} \\
\hline & $\begin{array}{c}\text { At } \\
\text { slaughter }\end{array}$ & $\begin{array}{c}\text { Hot } \\
\text { carcass }\end{array}$ & & Liver & Kidney & Heart & Head \\
\hline \multicolumn{8}{|l|}{ Caged system (CS): } \\
\hline Flat & 2217.63 & 1296.93 & 59.07 & 3.30 & 0.81 & 0.36 & 11.76 \\
\hline Semi pyramidal & 2121.70 & 1266.33 & 60.27 & 3.49 & 0.82 & 0.35 & 11.69 \\
\hline SEM & 20.65 & 28.51 & 1.20 & 1.11 & 0.95 & 0.03 & 0.35 \\
\hline Significance & $* *$ & NS & $*$ & $*$ & NS & NS & NS \\
\hline \multicolumn{8}{|l|}{ Feed additivse $(F A)$ : } \\
\hline Control & $2088.57^{\mathrm{b}}$ & $1233.95^{\mathrm{b}}$ & 60.15 & $3.45^{\mathrm{a}}$ & 0.83 & 0.35 & 10.89 \\
\hline Parsley (P) & $2088.67^{\mathrm{b}}$ & $1221.21^{\mathrm{b}}$ & 59.88 & $3.40^{\mathrm{ab}}$ & 0.84 & 0.34 & 11.10 \\
\hline Ginseng (G) & $2251.62^{\mathrm{a}}$ & $1329.49^{\mathrm{a}}$ & 59.79 & $3.31^{\mathrm{b}}$ & 0.80 & 0.34 & 11.53 \\
\hline $\mathrm{P}+\mathrm{G}$ & $2262.12^{\mathrm{a}}$ & $1335.61^{\mathrm{a}}$ & 60.05 & $3.50^{\mathrm{a}}$ & 1.81 & 0.35 & 10.86 \\
\hline SEM & 23.75 & 25.25 & 1.18 & 1.71 & 1.25 & 0.02 & 0.27 \\
\hline Significance & $*$ & $*$ & NS & $*$ & NS & NS & NS \\
\hline \multicolumn{8}{|c|}{ Interaction between $(C S)$ and $(F A)$} \\
\hline Significance & NS & NS & NS & NS & NS & NS & NS \\
\hline
\end{tabular}

a...d: Means denoted within the same column for each factor with different superscripts are significantly $(\mathrm{P}<0.05)$ different.

Additionally, no differences in the relative weight of liver was observed $(\mathrm{P}<0.05)$ due to supplementation of ginseng into the diets of broilers vs. the free one (control) as recorded by Ao et al.(2011). Also, (Abdel-Wahhab et al., 2012) demonstrated that panax ginseng extract (PGE) alone had no significant effects on serum biochemical parameters of liver and kidney function in rats. Moreover, the relative organ weights of liver, breast meat and gizzard did not while the level of abdominal fat was decreased $(\mathrm{P}<0.05)$ when diet of broiler chickens was supplemented by wild- ginseng adventitious root meal compared with control treatment (Yan et al., 2011). On the other hand, Ibrahim et al.(2004) reported that rabbits received either dill or parsley at $1.0 \%$ dose showed a significant $(\mathrm{P}<0.05)$ decrease in abdominal fat weight.

Results concerning the chemical analysis of rabbit meat (Table 6), showed that caged system significantly $(\mathrm{P}<0.05)$ affected $\mathrm{DM}$ and EE contents in which DM was higher while EE was lower with flat caged system compared to semi pyramidal caged system. However, dietary supplementation had no significant effect on rabbits meat chemical analysis (Table 6). Also results obtained indicated that chemical analysis of meat were not significantly affected by interaction between caged system and feed supplementation. 
Table (6): Chemical analysis of meat of rabbits as affected by caged system and feed additives and their interaction.

\begin{tabular}{lcccc}
\hline \multicolumn{1}{c}{ Items } & DM & CP & EE & Ash \\
\hline Caged system $(\boldsymbol{C S}):$ & & & & \\
Flat & 30.83 & 62.20 & 24.33 & 4.52 \\
Semi pyramidal & 22.06 & 61.81 & 25.88 & $4 . .44$ \\
SEM & 0.81 & 1.4 & 0.95 & 0.11 \\
Significance & $* *$ & NS & $* *$ & NS \\
Natural Feed additive (FA): & & & & \\
Control & 30.81 & 62.14 & 25.44 & 4.60 \\
Parsley (P) & 30.53 & 61.52 & 24.92 & 4.53 \\
Ginseng (G) & 30.11 & 62.81 & 25.22 & 4.44 \\
P+G & 30.70 & 61.33 & 24.66 & 4.33 \\
SEM & 2.42 & 1.37 & 1.11 & 0.32 \\
Significance & NS & NS & NS & NS \\
Interaction between $(C S)$ and (NFA) & & & & \\
Significance & NS & NS & NS & NS \\
\hline
\end{tabular}

a...d: Means denoted within the same column for each factor with different superscripts are significantly $(\mathrm{P}<0.05)$ different.

\section{Semen quality traits}

Results in Table (7) showed that most physical semen characteristics, including sperm cell concentration, sperm motility and dead spermatozoa significantly $(\mathrm{P}<0.05)$ improved by feeding rabbit bucks on diets supplemented with most natural feed additives, being the best values were associated with ginseng supplementation. However, semen ejaculate volume and percentage of sperm abnormality were not significantly affected by natural feed additives in buck diets. Azazi et al. (2011) showed that, semen quality was improved by supplementing ginseng to the layer diets. These findings were supported by Hong et al.,(1976) who found that increased seminiferous tubules diameter in cockerels receiving diet containing $100 \mathrm{mg} / \mathrm{kg}$ saponin. The larger testis was found in birds those received saponin and L- carnitine diets (Miah et al., 2004).

\section{Caecum microbial activity:}

Table (8) represents the results concerning the effect of dietary natural feed additives and their interaction on caecum microbial activity. Total count of bacteria and lactobacilli were significantly $(\mathrm{P}<0.05)$ higher in caecum content for rabbits received diets containing parsley, ginseng or their mix than those fed control diet. While ureolytic bacteria count for all supplements were significant lower than that of control that free from any supplement. Similarly, Simonová et al. (2008) reported that the antimicrobial effect of Eleutherococcus extract was observed by reduction of coagulase- positive staphylococci (CPS), staphylococcus aureus, 
EFFECTS OFDIETARY GINSENG ORPARSLEY SUPPLEMENTATIONINDIETSOFRABBITS 193 
clostridia and E. coli fasces $(\mathrm{P}<0.01)$. Microbial counts in caecum were lower than in faces and were slightly influenced during the extract application. The anticoccidial effect of herbal extracts are also known as revealed by the findings of (Youn and Noh, 2001). Pathogenic bacteria count (Escherichia coli and Clostridium spp.) were decreased $(\mathrm{P}<0.01)$ by supplementing all kinds of supplements in comparison those of control than have nothing supplement. Similarly to our results, Simonová et al.(2008) indicated that reduced counts of clostridia, E. coli and S. aureus were confirmed by Simonová et al. (2007a \& b) during the application chamomile essential oil ,as well as, of bacteriocin producing and probiotic strain Enterococcus faecium and its bacteriocin in rabbits.

\section{Economical efficiency:}

Data of economical evaluation (Table 9) showed that the cost of $1 \mathrm{Kg}$ gain was significantly $(\mathrm{P}<0.05)$ higher for semi pyramidal than for flat caged system (13.83 vs $13.50 \mathrm{EL} / \mathrm{Kg}$ gain), although total feed intake and their cost were significantly $(\mathrm{P}<0.05)$ lower with semi pyramidal than those of flat caged system. This was attributed to lower gain and consequently its price $(\mathrm{P}<0.05)$ with semi pyramidal as compared with flat system, which reflected significantly $(\mathrm{P}<0.05)$ on arising economical efficiency in flat in comparison with semi pyramidal caged system.

Concerning feed additives, rabbits fed ginseng with or without parsley supplemented diet showed the lowest $(\mathrm{P}<0.05)$ cost of one $\mathrm{kg}$ gain due to the highest $(\mathrm{P}<0.05)$ price gain and followed by the highest $(\mathrm{P}<0.05)$ economical efficiency as compared to other supplemented and control diets.

The effect of interaction between caged system and dietary supplementation on all data of economic evaluation was not significant (Table 9).

In conclusion : results of this study indicated that growing rabbits fed ginseng alone or with parsley supplemented diets and housed in flat caged system recorded the best growth performance and economical efficiency.

\section{REFERENCES}

Abdel-Wahhab, M.A.; Ibrahim, A.; El-Nekeety, A. A.; Hassan, N. S. and Amira A. Mohamed (2012). Panaxginseng C.A. Meyer extract counteracts the oxidative stress in rats fed multi-mycotoxins-contaminated diet. Comunicata Scientiae, 3(3): 143-153.

Anous, M.R. and Ayyat, M.S. (2002). Evaluation of carcass composition of NEW Zealand white rabbits raised in two different housing systems. Egyptian Journal of Rabbit Science, 12(2): 155-164. 
EFFECTS OFDIETARY GINSENG ORPARSLEY SUPPLEMENTATIONINDIETSOFRABBITS 195 
Ao, X.; Zhou, T.X.; Kim, H.J.; Hong, S.M. and Kim, I.H. (2011). Influence of fermented red ginseng extract on broilers and laying hens. AsianAustralasian Journal of Animal Sciences, 24(7): 993-1000.

AOAC. (2000). Association of Official Analytical Chemists. Official Methods Of Analysis $.17^{\text {th }}$ Ed. AOAC, Washington, DC,USA.

APHA, (1960). American Public Health Association. Standard Methods for the Examination of Dairy Products, 13th Ed. APHA, Inc. New York.

Attele, A. S.; Wu, J. A. and Yuan, C. S. (1999). Ginseng pharmacology: Multiple constituents and multiple actions. Biochem.Pharmacol., 58: 1685-1693.

Azazi, I.A.; Darwish, M.A.S.; Abd El Hamied, E.F.; Habib, A.A. and Razik, Y.S. (2011).Effect Of Dietary Ginseng Supplementation On Productive and Reproductive Traits For Sinai Layer Strain. Journal of productivity and Development Agricultural Research, 16(1). 287-305.

Azouz, H.M.M. (2001). Effect of hot pepper and fenugreek seeds supplementation on broilerdiets. Ph.D. Thesis, Poultry Nutrition Dept. Faculty of Agriculture, Cairo University.

Baselga, M. (1990). Genetic analysis models and selection in small populations of meat rabbits.Options Méditerranéennes: Série A. Séminaires Méditerranéens ; n. 8 : 35-39.

Brugalli, I. (2003). Alimentação alternativa: a utilização de fito terápico sounu tracêuticos como moduladores da imunidade e desempenho animal. Anais do Simposio sobre Manejo e Nutrição de Aves e Suínos; Campinas, São Paulo. Brasil. Campinas: CBNA; 167-182.

Carpenter, K.J. and Clegg, K.M. (1956).The metabolisable energy of poultry feeding-stuffs in relation to their chemical composition. J. Sci. Food Agric., 7: 45-51.

Cheeke, P.R. (1987). Rabbit Feeding and Nutrition. Academic Press, Orlando, Florida, USA.

Choi, K.T. (2008). Botanical characteristics, pharmacological effects and medicinal components of Korean Panaxginseng C A Meyer. Acta Pharmacol Sin., 29:1109-1118.

Chrastinová , L.; Chrenková, M.;.:Lauková, A.;Poláčiková, M.;Simonová, M.; Szabóová, R.;Strompfová, V.; Ondruška,L.;Chlebec, I.; Parkányi , V.; Rafay, J.; Vasilková, (2009).Utilization of anextract product from ginseng supplementation in diets and different energy levels of granulated feed in the nutrition of rabbits. Archiva Zootechnica, 12(1): 72-79.

Difco Mannual (1977). Dehydrated Culture Media and Reagents, Difco Labora-tories. Detroit, MIichigan, USA. 
EFFECTS OFDIETARY GINSENG ORPARSLEY SUPPLEMENTATIONINDIETS OFRABBITS 197

Duncan, D. B. (1955). Multiple range and multiple F -tests, Biometrics, 11: 142.

Faixova, Z. and Faix, S.(2008). Biological effects of rosemary (Rosmarinu soficinalis) essential oil (a review). Folia Veterinaria, 52: 135-139.

Fascina, V.B.; Sartori , J.R.; Gonzales, E.; de Carvalho, F. B.; de Souza, I. M. G. P. ; Polycarpo , G. V.; Stradiotti , A. C. and Pelícia, V. C. (2012).Phytogenicadditives and organicacids in broilerchickendiets. $R$. Bras. Zootec., 41(10).2189-2197.

Gornall, A.G.; Bardawill, C.J. and David, M.M. (1949). Determination of serum proteins by means of the biuret reaction. Journal Biol. Chem., 177:751-766.

Holst, P.B. and Engvild, K.C. (2000).Natural chlorinated compounds. 17th Danish plant Protection Conference Overview / environment / weeds. DJF -Rapport, Markbrng, No. 23, 87-95.

Hong, B.J.; Kim,C.I. U.H. and Rec, Y.C. (1976). Effect of feeding ginseng crude saponin extracts on body weight gain and reproductive function in poultry. Kor. J. Anim. Sci., 18: 355-361.

Ibrahim, S. A. M.; El Yamny, A. T.; Zeid, A. M. M., (2004). Dill and parsley as growth promoters in White Modified Zealand growing rabbits. Egyptain Poultry Science, 24:917-927.

Ibrahim, S.A.M., (2005). Effect of some medicinal plants as feed additives on growth and some metabolic changes in rabbits. Egyptian J. Nutrition and feeds, 8(2): 207- 219.

Jang, H.D.; Kim, H.J.; Cho, J.H.; Chen, Y.J.;Yoo, J.S.;Min, B.J.; Park, J.C. and Kim, I.H. (2007). Effects of DietarySupplementation of Fermented Wild-ginseng Culture By-productsonEggProductivity, EggQuality, BloodCharacteristics and GinsenosideConcentration of Yolk in LayingHens. Kor.J. Poultry Science, 34:271- 278.

Kang, S.Y.; Kim, S.H.; Schini, V.B. and Kim, N.D.(1995). Dietary ginsenosides improve endothelium-dependent relaxation in the thoracic aorta of hyper cholesterolemic rabbit. Gen Pharmacol., 26:483- 487.

Kim, H.G.; Yoo, S.R.; Park, H.J.; Lee, N.H.; Shin, J.W.; Sathyanath, R.; Cho, J.H.and Son, C.G.(2011). Antioxidant effects of Panax ginseng C.A. Meyer in healthy subjects: A randomized, placebo-controlled clinical trial. Food Chem. Toxicol., 49(9):2229-35.

Kim, H. Y.; Kang,K. S.; Yamabe,N. and Yokozawa, T. (2008). Comparison of the effects of Korean ginseng and heat-processed Korean ginseng on diabetic oxidative stress.Am J Chin Med.,36 (5):989-1004. 
Lebas, F. ;Coudert, P. ; Rouvier, R. and de Rochambeau, H. (1986). The rabbit : Husbandry and Health. FAO Animal Production and Health Series, no. 21. Rome, $235 \mathrm{pp}$.

Lebas, F. and Ohayoun, J.(1987). Incidence duniveauproteique de l'aliment, du milieu d'elevage et de la saisonsur la croissance et les qualitesboucheres du lapin .Ann. Zootechn., 36:421-432.

Lee, L.S.; Cho, C.W.; Hong, H.D.; Lee, Y.C.; Choi, U.K.and Kim, Y.C. (2013). Hypolipidemic and antioxidantproperties of phenoliccompoundrichextractsfromwhiteginseng (Panaxginseng) in cholesterol-fedrabbits. Molecules., 18(10):12548-60.

Lim , S.; Yoon, J.W.; Choi, S. H.; Cho, B. J.; Kim, J.T.; Chang, H.S.; Park, H.S.; Park, K.S.; Lee, H.K.; Kim, Y.B. and Jang, H.C. (2009). Effect of ginsam, a vinegar extract from Panax ginseng, on body weight and glucose homeostasis in an obese insulin-resistant rat model. Metabolism., 58(1):8-15.

Lü, J.M.; Yao, Q. and Chen, C.(2009). Ginseng compounds: an update on their molecular mechanisms and medical applications. CurrVasc Pharmacol., 7(3):293-302.

Mackie, T.J. and McCartney, J.E. (1953). Handbook of Practical Bacteriology. A guide Bocteriology Laboratory Work . 9th Edition, Livingstone 1T d, Edinburgh and London .

Miah , M.Y.; Rahman , M.S.; Islam M.K. and Monir,M.M. (2004).Effects of Saponin and L-Carnitineonthe Performance and ReproductiveFitness of MaleBroiler. International Journal of PoultryScience 3 (8): 530-533.

Ndor, L.; Owen, O.J. and Nyeche, V.N. (2010). Influence of Housing Systems on the Performance and Reproductive Characteristics of Wearner Rabbits Reared in Port Harcourt, RiversState, Nigeria. International Journal Of Agriculture and Biology, 12(6):947-949.

NRC(1977).National Research Council. Nutrient requirements of rabbits. Nat. Acad. Sci., Washington, DC., USA.

Owen, J. E. (1994). Structure and materials .In: livestock housing wathes,C.M. and Charles, D.R.(Eds.),CAB Inter. Wallingford, Oxon, UK.

Palazon, J.; Cusido, R. M.; Bonfil, M.; Mallol, A.; Moyamo, E.; Marales, C. and Pinol, M. T. (2003). Elicitation of different Panax ginseng transformed root pheno types foran improvement ginsenoside production. PlantPhysiol. Biochem., 41:1019-1025.

Qureshi, A. A.; Din, Z.Z.; Abuirmeileh, N.; Burger, W.C.; Ahmad, Y. and Elson C.E. (1983). Suppression of avian hepatic lipid metabolism by solvent extracts of garlic: impact on serum lipids. J. Nutr., 113(9):1746-55. 
EFFECTS OFDIETARY GINSENG ORPARSLEY SUPPLEMENTATIONINDIETS OFRABBITS 199

Rabie, M.H. and Szilágyi, M. (1998). Effects of L-carnitinesupplementation of dietsdiffering in energy levels on performance, abdominal fat content, and yield and composition of edible meat of broilers. Br. J. Nutr., 80 (4):391400.

Rabie, M.H.; Szilágyi, M.; Gippert, T.; Votisky, E. and Gerendai, D.(1997). Influence of dietary L-carnitineon performance and carcass quality of broiler chickens. Acta BiolHung., 48(2):241-52.

Richmond, A.C.K. and Mackley, S.M.L. (2000). Herbs and Spices. $2^{\text {nd }}$ Edn., Review of Natural Products, 1991. Facts and Comparisons; Parsley Monograph. St. Louis, MO. Lorenz Books Anness Publishing Inc., London, UK.

SAS Institute Inc.(2004) SAS/STAT. User's Guide, Version 9.1.3, SAS Inst., Cary, NC.

Shim, J.Y.; Kim, M.H.; Kim, H.D.; Ahn, J.Y.; Yun, Y.S. and Song, J.Y. (2010). Protectiveaction of theimmunomodulatorginsanagainstcarbon tetrachloride-induced liver injury via control of oxidative stress and the inflammatory response. Toxicol. Appl. Pharmacol., 242:318-325.

Simonová, M. P.; Chrastinová, A. L'; Strompfová, V.; Faix1, Š. ;Vasilková, Z.; Ondruška, L.; Jurčík, R. and Rafay, J. (2007a). Entero coccus faecium CCM7420, bacteriocin PPB CCM7420 and their effect in the digestive tract of rabbits. Czech J. Anim. Sci., 54: 2009 (8): 376-386.

Simonová, M.; Szabóová, R.; Chrastinová, L'; Lauková, A.; Haviarová, M.; Strompfová, V.; Plachá, I.; Faix, Š.; Vasilková, Z.; Mojto, J. and Rafay, J. (2008). The Use Of A Ginseng Extract In Rabbits $.9^{\text {th }}$ World Rabbit Congress - June 10-13, Verona - Italy.

Simonová, M.P.; Strompfová, V.; Marciňáková, M.; Haviarová, M.; Faix, S.; Lauková, A.; Vasilková, Z. and Salamon, I. (2007b). Chamomile essential oíl and its experimental application in rabbits. Acta Horticulturae, 749:197-201.

Smyth, P. and Gordon, I. (1967). Seasonal and breedvariations in the semen characteristics of rams in Ireland. Ir. Vet. J., (21):222-233.

Solanke, O.F. and Awonorin, S.O. (2002).Kinetics of Vit.C degradation in some tropical green leafy vegetables during blanching. Nigerian Food Journal, 20: 24-32.

Spelman, K.; Burns, J. and Tenborg, M. (2006). Modulation of cytokine expression by traditional medicines: areview of herbal immunomodulators. Altern. Med. Rev., 11:128-150.

Sticher, O. (1998) .Gettingtotheroot of ginseng. Chemtech, 28: 26-32. 
Takahashi, M.1.; Tokuyama, S. and Kaneto, H. (1992). Anti-stress effect of ginseng on the inhibition of the development of morphine tolerance in stressed mice. Japn J. Pharmacol.,59 (3):399-404.

Tietz, N.W. (1994). Textbook of clinical chemistry, $2^{\text {nd }}$ Ed.W.B. Saunders compang, Philadelphia, PA, 703.

Trout, J.M.1.; Mashaly, M.M. and Siegel, H.S. (1996).Changes in blood and spleen lymphocyte populations following antigen challenge in immature male chickens. British Poultry Science, 37(4):819-827.

Wu, J. and Zhong, J.J. (1999). Production of ginseng and its bioactive compounds in plant cell culture: Current technological and applied aspects. J. Biotechnol., 68:89-99.

Yan, L.; Meng, Q. W.; Lee, J. H.; Wang, J. P. and Kim, I. H. (2011). Effects of Dietary Wild-ginseng Adventitious Root Meal on Growth Performance, Blood Profiles, Relative Organ Weight and Meat Quality in Broiler Chickens. Asian-AustralasianJournal of Animal Sciences, 24 (2): 258-263.

Yildirim, A. and Erener, G., (2010). The possibilities Using of Ginseng (Panax Spp.) in Poultry Nutrition. Hasad Journal of Animal Science, 26 (307):5659. (In Turkish).

Youn, H.J. and Noh, J. W. (2001). Screening of theanticoccidialeffects of herbextractsagainstEimeriatenella. VeterinaryParasitology96, (4): 257263.

Zhang, Q. H.; Wu,C. F.; Duan,L. and Yang, J. Y. (2008).Protective effects of total saponinsfromstem and leaf of Panaxginseng against cyclophosphamide-inducedgenotoxicity and apoptosis in mouse bone marrow cells and peripheral lymphocyte cells. Food Chem. Toxicol., 46(1):293-302.

$$
\begin{aligned}
& \text { تأثثر إضافة كلا من مستخلص الجنسج أو مسحوق ورق البقدونس الجاف } \\
& \text { فى علاق الأرانب الناميه المرباه تحث تصميمين مختلفين لنظم التسكين فى افى اونى } \\
& \text { الأققفاص } \\
& \text { حنان احمد محمود حسنين- رجاء السيد عبد الكريم }
\end{aligned}
$$

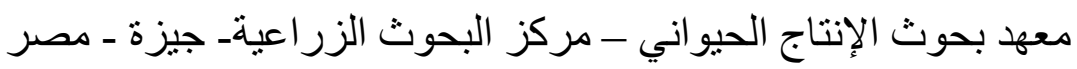

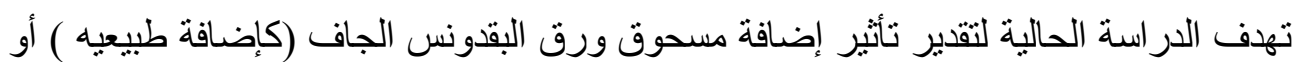

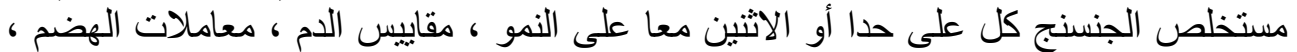

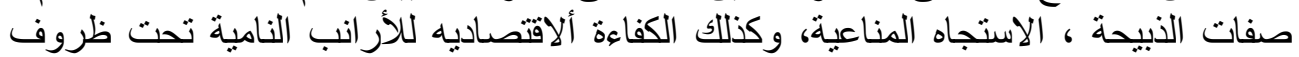


EFFECTS OFDIETARY GINSENGORPARSLEY SUPPLEMENTATIONINDIETSOFRABBITS201 تصميميين مختلفين للتسكين في الأقفاص (تصميم مسطح أو شبه الهرمي) ، بالاضافه الى در اسة

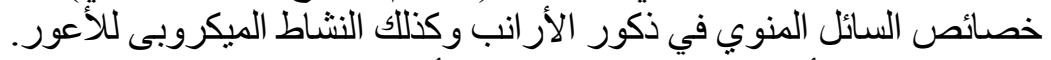

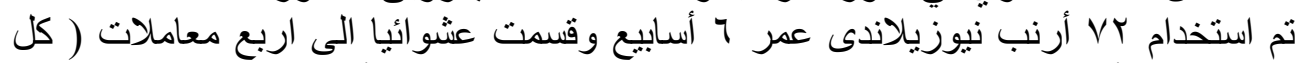

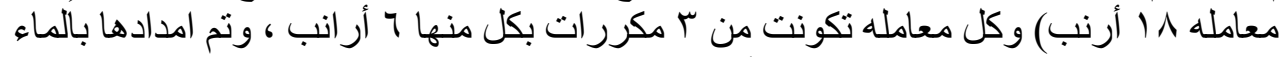

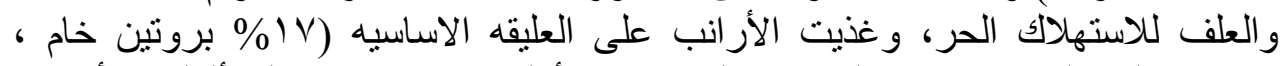

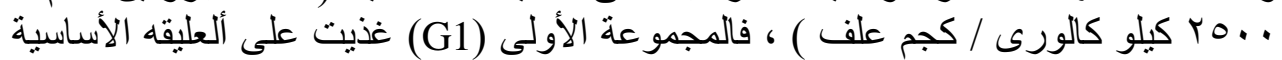

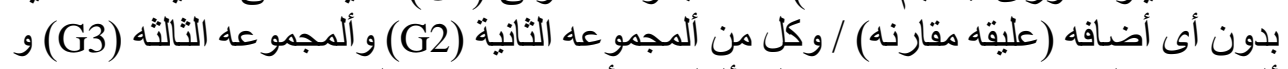

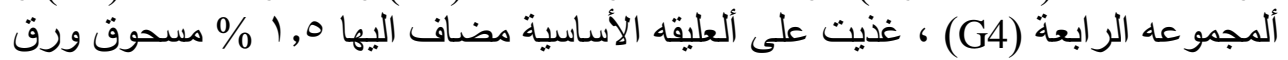

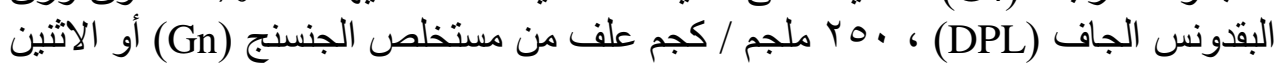

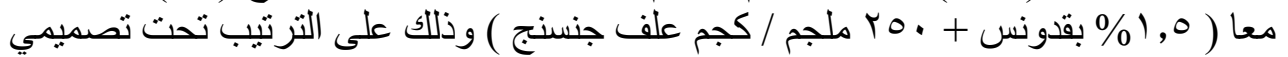

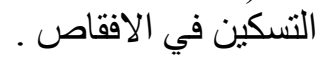

أوضحت النتأيج المتحصل عليها تحت ظروف تصميميين مختلفين لنظم التسكين في الأقفاص على ما يلي:

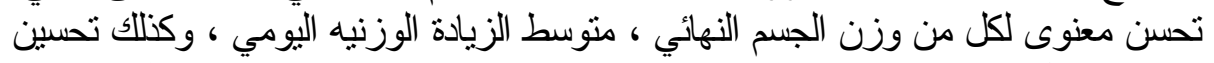

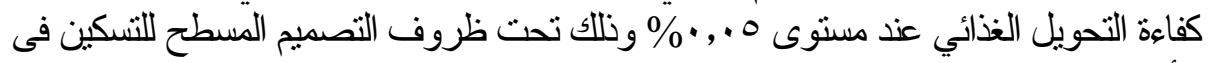

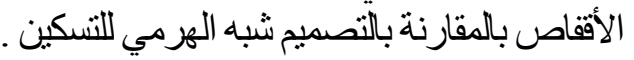

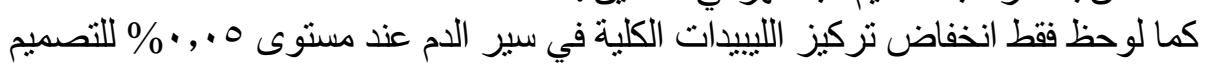

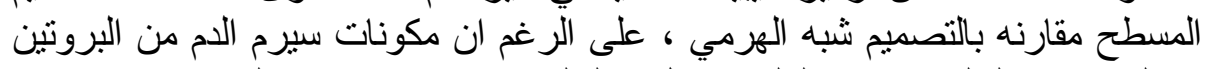

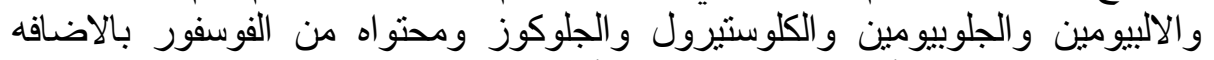

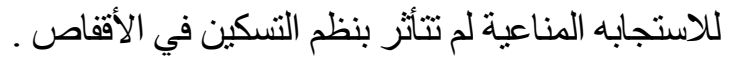

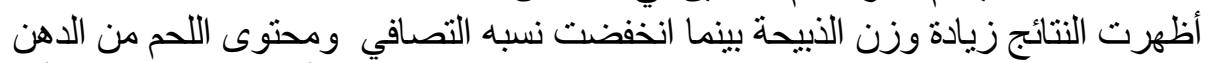

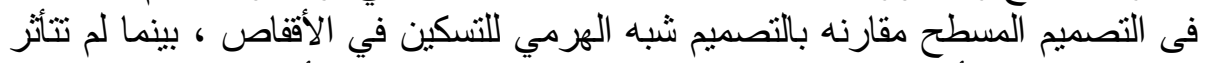

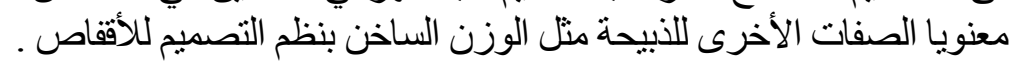

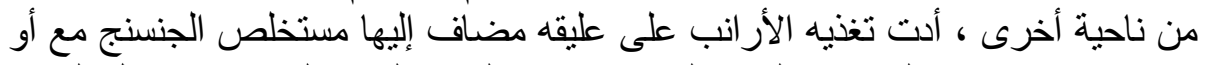

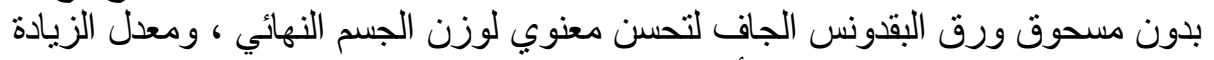

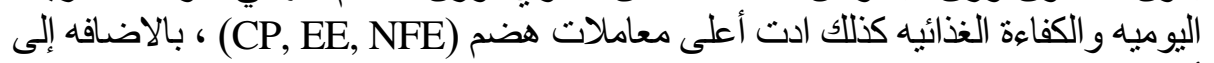

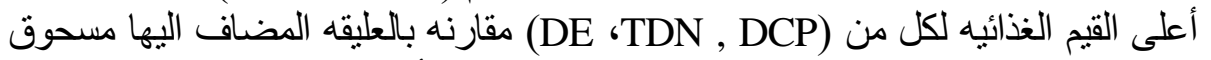

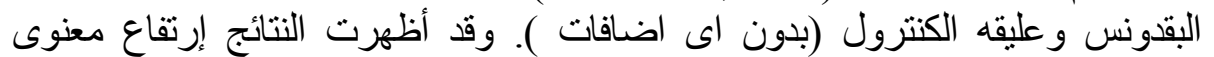

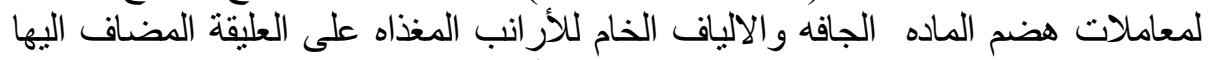

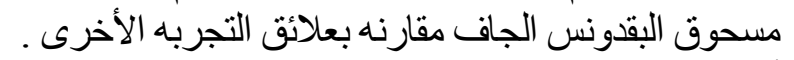

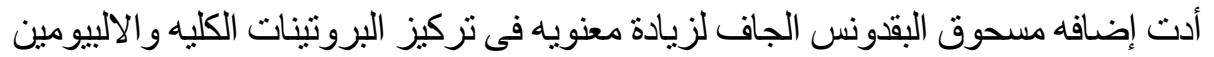

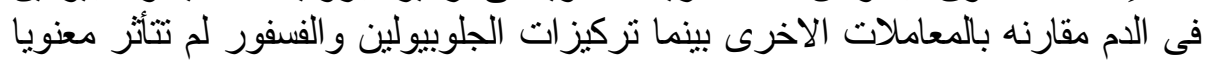

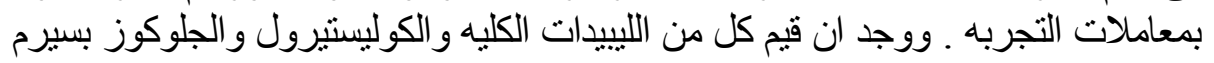

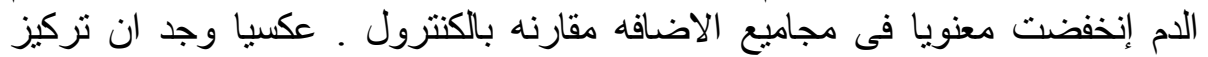

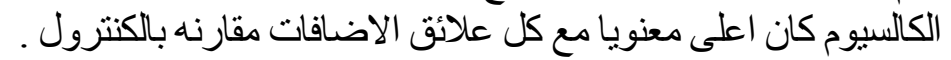

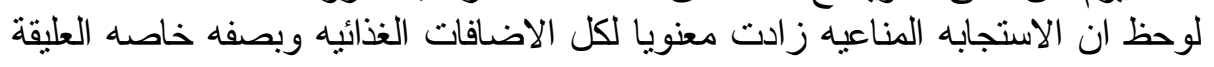

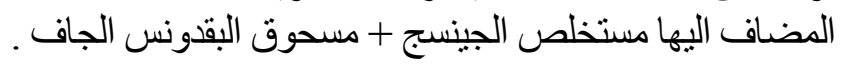


أدت إضافه مستخلص الجنسج بمفرده او مع مسحوق البقدونس الى العلائق لزيادة معنويه

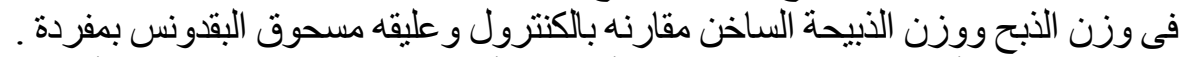

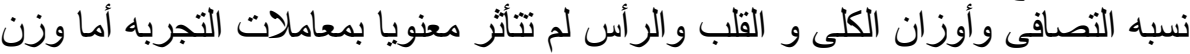

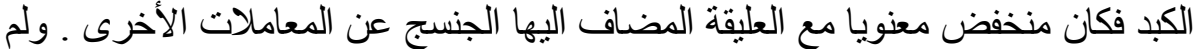

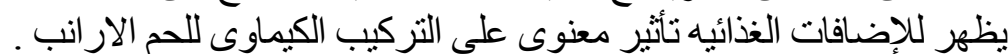

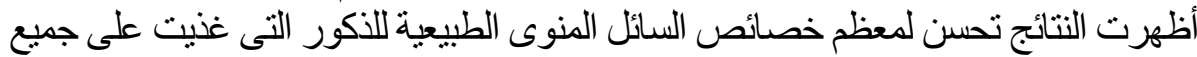
العلائق المختبره مقارنه بالكنترول بما فى ذلك زيادة تركيز الحيوانات المنويه الطبيعية

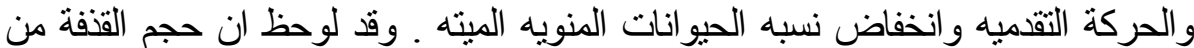

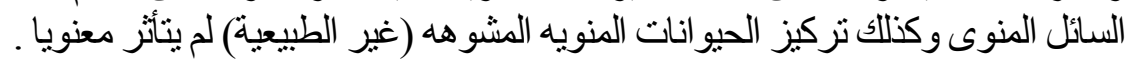

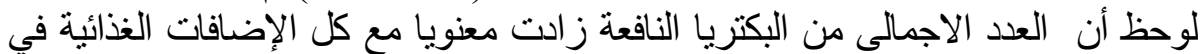

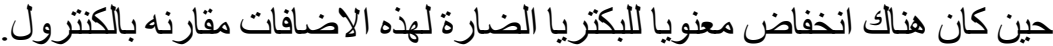

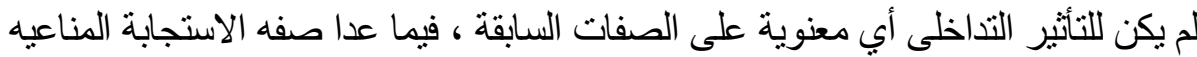

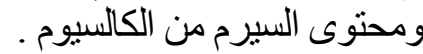
من الناحيه الاقتصادية ، أظهرت النتائج ان الأرانب التي غذيت على عليقه مضاف إليها مستخلص الجنسج تحت ظروف التربية فى إقفاص مسطحه التصميم كانت هى الإنى الاعلى فى التى الته الكفاعة الاقتصاييه .

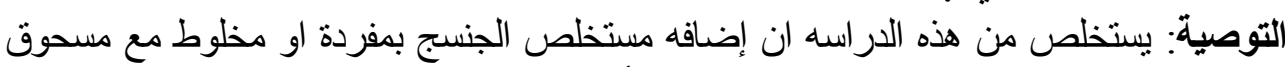

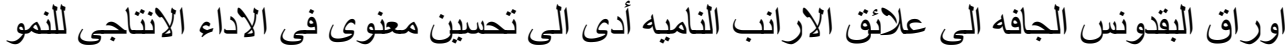

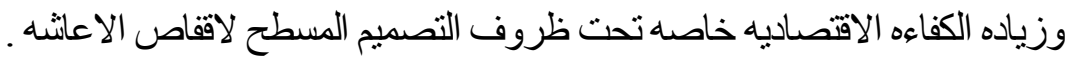

